\title{
The New Mexico AMP: Preparing Minorities for Careers in Science, Mathematics, Engineering and Technology
}

\author{
Ricardo B. Jacquez, Rudi Schoenmackers, \\ Carol Lopez Fischer, Anthony Parra and Kathleen Kelsey \\ New Mexico Alliance for Minority Participation \\ New Mexico State University \\ Box 30001, Dept. 3AMP \\ Las Cruces, NM 88003-8001
}

\begin{abstract}
The New Mexico Alliance for Minority Participation (New Mexico AMP) is a partnership of 26 of New Mexico's post secondary institutions including the state's 20 public two-year community colleges. New Mexico AMP is funded by the National Science Foundation (NSF) for a period of five years, November 1993 through October 1998, at a level of five million dollars. The goal of the Alliance is to increase the state's graduation rate of ethnic minorities - African Americans, Hispanic Americans, American Indians, Alaskan Natives and Pacific Islanders - in science, mathematics, engineering, and technology from 253 per year (1992) to over 700 per year by 1998.
\end{abstract}

\section{Overview}

To ensure that the United States remains the most productive and efficient country in the scientific and technological world requires our workforce to be representative of society. With a graduation rate of 4.8 percent among underrepresented minorities nationwide, there is a need for the science, mathematics, engineering, and technology (SMET) disciplines to diversify their make-up. This effort must include outreach to and opportunities for Hispanics, American Indians, African Americans, Alaskan Natives and Pacific Islanders who have historically not made up a representative portion of university SMET graduates.

New Mexico has one of the highest populations of underrepresented minorities in the nation. Through the New Mexico AMP this large pool of talent is poised to provide major contributions to diversify the ethnic base of students receiving undergraduate and graduate degrees.

The AMP program is NSF's national flagship initiative for increasing the participation of individuals from minority groups underrepresented in the SMET work force. For over two years, the New Mexico AMP has successfully engaged the resources of the scientific community in a statewide initiative aimed at increasing the numbers of minority individuals receiving baccalaureate degrees in SMET fields. Specific project activities include:

- Developing articulation agreements

- Providing recruiting and retention programs

- Providing courses by distance learning

- Establishing internships

- Providing scholarships and student stipends

- Maintaining a comprehensive tracking system

The goal of the New Mexico AMP is to increase the number of baccalaureate degrees awarded to underrepresented minorities in SMET fields in New Mexico from 253 in the baseline year of 1992/93 to 
over 700 annually by 1997/98. Significant gains have been by the New Mexico AMP during the first two years:

- The number of baccalaureate degrees awarded to minorities in SMET fields in New Mexico increased from 253 in 1992/93 to 336 in 1994/95 -- a 33 percent increase.

- American Indian graduates from New Mexico AMP universities represent 3 percent of all SMET graduates compared with a 0.4 percent national average. Hispanic graduates represent 28 percent of all SMET graduates compared with a 4 percent national average.

- The full-time enrollments of African American, American Indian, and Hispanic undergraduates in SMET fields increased about 1 percent, led by a 4.7 percent increase in science enrollment.

- Distance learning using videotapes and satellite broadcasts expanded course offerings at New Mexico AMP institutions. Eight partners enrolled 45 students during the first year.

\section{Partnerships}

The New Mexico AMP has successfully established partnerships between the state's 26 institutions of higher learning. These partner institutions are:

- Albuquerque Technical Vocational Institute

- Clovis Community College

- $\quad$ Eastern New Mexico University (ENMU)

- ENMU Roswell

- ENMU Ruidoso

- Luna Vocational Technical Institute

- Mesa Technical College

- Navajo Community College

- New Mexico Highlands University

- New Mexico Institute of Mining \& Technology

- New Mexico Junior College

- New Mexico Military Institute

- New Mexico State University (NMSU)
- NMSU Alamogordo Branch

- NMSU Carlsbad Branch

- NMSU Doña Ana Branch

- NMSU Grants Branch

- Northern N.M. Community College

- San Juan College

- Santa Fe Community College

- Southwestern Indian Polytechnic Institute

- University of New Mexico (UNM)

- UNM Gallup Campus

- UNM Los Alamos Campus

- UNM Valencia Campus

- Western New Mexico University

Partnerships with Los Alamos National Laboratory and Sandia National Laboratories are also in place.

As the contracting partner for the Alliance, New Mexico State University (NMSU) has subcontracted over 70 percent of the program funds to other New Mexico AMP partners to address local needs and opportunities. Activities made possible by New Mexico AMP support include:

- Scholarships and stipends

- Tutoring

- Mentoring

- Equipment

- Summer bridge programs
- Recruiting

- Articulation agreements/transfer guides

- Distance learning

- Guest speakers

- Research opportunities

\section{Database}

The New Mexico AMP has established a comprehensive database. Among the information provided by the database is demographic data about students, faculty, and institutional partners, student grade performance, student exit and transfer information, student financial support history, and evaluation and assessment data. 


\section{Articulation Agreements}

Articulation agreements serve as the cornerstone for the New Mexico AMP. These agreements between two-year and four-year institutions allow students earning credit in SMET-track courses to receive the same credit at other institutions when transferring. The articulation agreements are described in reader-friendly transfer guides for students. The guides describe the courses and course equivalents which students should complete at two-year colleges that will transfer to four-year universities. Over 60 different guides have been completed since the program's initiation, eight are still in progress.

\section{Retention}

Although the New Mexico AMP tailors retention activities to each institutional partner's needs, each local program is composed of the same components: scholarships that make a difference in the students' ability to remain in college, cooperative learning and group study to encourage team building and improve study skills, tutoring programs that improve student skill levels and build confidence, mentoring programs that provide direct guidance, support, and role models, and guest speakers and field trips that provide students with the opportunity to learn more about their intended fields as career opportunities.

\section{Recruitment}

The New Mexico AMP model is designed to help two-year colleges recruit, educate, and transfer qualified SMET students into four-year universities. This approach recognizes that attendance at a local two-year college is often more affordable, convenient, and comfortable for students.

\section{Summer Bridge Programs}

Summer bridge programs help students succeed in SMET courses that SMET majors are required to pass early in their college careers. Bridge programs help students advance through critical transition points between secondary and postsecondary education. AMP summer bridge programs are offered at:

- Clovis Community College

- Eastern New Mexico University

- Navajo Community College

- New Mexico Junior College

- New Mexico Institute of Mining \& Technology
- NMSU Carlsbad Branch

- NMSU Doña Ana Branch

- San Juan College

- Santa Fe Community College

- UNM Gallup Campus

\section{Summer Internship Program}

The New Mexico AMP and Los Alamos National Laboratory have instituted a summer program to provide students with SMET research experiences in two areas: 1) at a university during the first summer; 2) at a national laboratory during the second summer.

New Mexico AMP also sponsored an internship program in conjunction with New Mexico Mathematics, Engineering, Science Achievement, Inc. During the summer of 1995, ten New Mexico high school graduates were assigned mentors and conducted research in their selected SMET majors. All students are now enrolled in New Mexico colleges and universities.

New Mexico AMP staff seek out additional internship opportunities for New Mexico AMP students nationwide. Letters have been sent to White Sands Missile Range, the National Aeronautics and Space Administration, and the Air Force Phillips Laboratory asking them to consider becoming formal New Mexico AMP partners and providing support for interns. 


\section{Legislative Effort}

New Mexico AMP, in partnership with the Regional Alliance for Science, Engineering, and Mathematics for Students with Disabilities (RASEM), is working with NM Senators and Representatives to put forth bills in the House and Senate during the 1996 legislative session to formally request $\$ 750,000$ for the two programs under the title "Alliances for Underrepresented Students." The New Mexico Commission on Higher Education supports this effort and is recommending that the legislature approve a funding request.

\section{Subcontracting Changes}

The New Mexico AMP has changed the way funding is allocated to its 26 partners for the coming year. During the first two years, the New Mexico AMP Board of Governors set the policy for fund distribution, with 2year colleges receiving a specific amount and 4-year universities receiving a different, but equal, amount. The process is now competitive, which has created some unique challenges for the program.

\section{Summary}

The New Mexico AMP provides an exceptionally solid foundation for increasing the number of minority science, mathematics, engineering and technology graduates. The program is producing new groups of talented minority individuals with high quality undergraduate training in SMET. The strong preparation that the New Mexico AMP provides in these disciplines can be built upon to prepare a new cadre of talented minority undergraduates for graduate school, industry, federal and state government, and K-12 teaching in science and mathematics. 